\title{
Seeing and Being the Visualised 'Other': Humanitarianism Representations and hybridity in African Diaspora identities.
}

Edward Ademolu ORCID: 0000-0002-5122-6232

Department of Methodology, London school of Economics and Political Science, London, UK

\begin{abstract}
This article examines how humanitarianism representations affect British Nigerian identities. It problematises the tendency within development literature to uncritically generalise British audiences of NGO representations as seemingly white. Studies further assume audiences interpret and are impacted by representations in largely undifferentiated ways. This assumption discounts the complexities and particularities of and within audiences and overlooks how humanitarian representations inform how (and why) audiences negotiate their racialised subjectivities. Applying Bhabha's hybridity theory, this article reveals how Nigerian diaspora negotiate racialised identities vis-à-vis humanitarian representations in distinct and revelatory ways, including along the lines of social class. These Nigerian subject-makings are contingencies against problematic portrayals of Black African poverty and perceived racism mediated by whiteness. While focused on Nigerians, this work has implications for the racialised realities of UK-based Black Africans.
\end{abstract}

Article History: Received 20 Feb 2019; Accepted 02 October 2019

Keywords: Representations, humanitarianism, African diaspora, Nigerian identities, hybridity, whiteness.

\section{Introduction}

Intraorganisational pressures, departmental politics and the economic determinants under which humanitarian agencies operate has meant that humanitarianism in today's rapidly changing media and communications environment, is now huge business, like any other, in our image-as-currency world. On television screens, social media applications, unsolicited popup email advertisements, and bus shelter posters -the public face(s) of the aid industry is seldom hidden. Whether a hungry child and helpless mother or a vast horde of shaven-headed, undifferentiated Black-and-Brown masses. These faces are the commercialised currencies used by humanitarian agencies to market themselves, their mission and most importantly, imbue audiences with philanthropic agency. As such, visual representations are central to the phenomenon of humanitarianism. When we think of humanitarianism we often imagine much of the non-western world through carefully curated illusions and allusions advanced by aid agencies and popular media. As image producers and disseminators, these organisations exercise a locus of control in social construction over who or that which is represented, but more significantly, how it is represented and for whom. 
Appropriately, there are studies -mainly within critical and mainstream development literature- which have increasingly acknowledged and analysed the influential role that representations of humanitarianism have had on how different, largely western-situated communities comprehend, perceive and engage with people and places of the global South and especially, Africa. This has mainly been examined in the context of measuring audiences' donating and philanthropic propensity (see, e.g., Dogra 2006; Kennedy 2009); examining how representations mediate intimate-distant alliances between viewers and the viewed (see, e.g., Boltanski 1999; Chouliaraki 2006; Silverstone 2007); or understanding the different ways that communities located in developed countries construe the so-called 'Third World' (see, e.g., Van der Gaag and Nash 1987; DFID 2000; VSO 2001; Darnton and Kirk 2011; Dogra 2012).

While this scholarship provides interesting and critical insights into how these representations inform and shape communities' subjectivities, dispositions and engagement in relation to 'faraway Others' in varied and complex ways. There is a tendency in much of this literature to present white hegemonic interpretations of British audiences of NGO representations. That is, visions of a community who are assumed self-evidently white, and seemingly devoid of racial differentiation and contradictory elements. These studies further assume audiences interpret and are impacted by such images in largely undifferentiated ways. This is problematic as it affords limited intellectual space to understand Black African marginalised perspectives of mediated communication (Ademolu, 2019), and omits the multiple, differentiated and idiosyncratic ways that their identities are constituted in, through and even against representations of humanitarianism

Privileging marginalised Black African experiences is incredibly important given the regime of racialised visual representation that humanitarian organisations are implicated in and which they legitimise. This 'regime' is dually-constituted by a "racialised knowledge of the non-white/western/European, 'Black African 'Other" and by what Willoughby-Herard (2015, 3 ) identifies as a "global regime of whiteness 1 ". This is nourished, supported and maintained, through innumerable acts of reiteration and reinforcement, partly by the representational practices of largely white-owned-and-run philanthropic corporations, such as povertyalleviating NGOs. According to Moeller (2018), racialised regimes of representation thrive within the humanitarian and international development professional environment, as this provides a legitimising space for NGOs - who are apparatuses of development practice, which in turn is necessarily historicised by and implicated in white supremacist discourse - to secure their hegemony by incorporating and neutralising racist discursive strategies. Strategies, utilised by predominantly (and historically) white NGO communication departments, which (and who) deploy colonial modes and tropes of racial stereotypes and simplification in humanitarian representations of Africa. Which construct monolithic and essentialised forms of identity for communities (of, and therein) racialised as Black, and that which are problematically presented as seemingly normative and commonsensical evaluations of racial typicality among (and for) those of African heritage. Including, but not limited to, pictorial illusions and allusions of invariant poverty, death, hunger, disease and helplessness among Blacks Africans alleviated only by western aid and other allied forms of foreign benevolent intervention.

In this way, humanitarian representations - imbued with 'racialised knowledge' and regime of whiteness - reflect and reproduce dominant asymmetrical power/knowledge relationships and structural oppressions of racial inequality. These uneven social relations are made between Black marginalised communities who are mediated by racialised and 
geographically imagined representations of poverty and correspondingly, of those NGOs (as apparatuses of whiteness), who image and strive for poverty's end (Moeller, 2018). As such, humanitarian representations are incredibly powerful and influential in that they wield (are wielded in) a certain level of disproportionate control and 'claim' over identities undergirded by whiteness, which determine and organise a set of ideas, perceptions and normative assumptions about how Black racialised audiences of African heritage are defined and comprehended.

Given that audiences are neither homogenous nor seemingly straightforward, but rather numerous, differentiated interpretative communities who are active appropriators and remakers of meaning (Hall [1973]1980). Within this framing, this article argues that communities bring a multiplicity of interpretations, positionalities and contradictions in how they read, respond to, and are personally affected by humanitarian representations. As such, visual representation by NGOs can and does affect different groups in different ways. One such group of people are Nigerian diaspora from the UK -who locate their ethnoracial ${ }^{2}$ heritages within the regions and among the communities that are portrayed in humanitarian representations.

Little is empirically known about how these representations influence Nigerian audiences. By influence I mean, how Nigerian identities are implicated, (re)constituted and strategically negotiated in relation to humanitarian representations which depict their continent and/or country of origin. What role, if anything, does NGO representation have in identity for Nigerian diaspora? Are we to assume that these popular images, which are often provocative, challenging and racialised in particularly negative and stereotypical ways, are inconsequential or secondary to how diaspora view and negotiate understandings of who they are? Or are they much more significant and constitutive than we think? As such, all these speculative questions and theoretical possibilities construct the frame within which this article is located.

While focusing on Nigerians, this gap in knowledge and attendant empirical lines of inquiry, nonetheless draws attention to limited scholarship on diaspora Africa(n) identities and humanitarian representations. That is, how we understand the different, complex and contradictory ways that the identities of UK-situated communities of African heritage, are constituted through - and even against - NGO representations of humanitarianism. Situating humanitarian representations within the unique context of Nigerian diaspora as a different or 'specific' kind of audience, will not only tell us more about how African diaspora identities are contextual and relational vis-à-vis representations. Drawing from Bhabha's (2013) 'Hybridity' theory, it also adds contextual specificity and cultural nuance to current understandings of diaspora identities as being multiple, inconsistent, provisional, and most important, as necessarily implicated in and through images. This will open-up critical insights into the complex subtleties of the 'how's' and 'why's' behind diaspora audience' subject-making. Suitably, this article develops appropriate responses to this lack of scholarship by examining the interconnections between NGO representations and Nigerians which has implications for broader UK Black African diaspora.

\section{Methodology}

This article concerns research which asks (and answers) 'how' and 'why' questions by examining African diaspora (inter)subjectivities in relation to visual representation, as a form of social reality and knowledge production. As such, the methodology and methods needed to produce data that was rich in thick description, subjectivity, and context constructed freely by people themselves. Suitably, a qualitative methodology was adopted employing focus group 
interviews. Focus groups are productive in exploring and analysing people's in-depth views and encourage debate, discussion and exchange of perspectives, interpretations and experiences unlike individual interviews (Gilbert 2008).

A total of seven focus groups with 31 diaspora participants were conducted. All participants were aged between 18-65 years old. Focus group segmentation was based on predetermined theoretical propositions and relevant literature. This comprised of Black British people of Nigerian heritage who were first and second generation and from different educational, professional and socio-economic backgrounds. In the context of this research this included those people born and/or who schooled in the UK, having arrived as children, or those who were the children of parents who had.

Suitably, it is worth noting the distinct "Nigerianness" of the research, that is, my interest and focus on Nigerians. This article is concerned with humanitarian representations and diaspora communities, appropriately, Nigeria and its diaspora communities are model cases for which to study. Nigeria has long been the foci of humanitarian representation, by British and European agencies. The 1967-1970 Nigeria-Biafra Civil War is the earliest documented example of how Nigeria, communities therein and its diaspora were subject to humanitarianism's visual frame. While, recent examples of Islamic terrorism by Boko Haram, in Northern Nigeria and the Ebola Virus outbreak both in 2014, has seen Nigeria and Nigerian's re-enter public and NGO consciousness.

Furthermore, one in every seven-Black people in the world is Nigerian. Historical immigration to Britain and especially its histories of colonialism, has meant that it hosts many different, long-established and newly-formed communities of Nigerian heritage (Alakija 2016).

The decision to examine the empirical realities of British Nigerians was also based on personal interest in Nigerians from being Nigerian myself. Issues of identity and positionality are necessarily implicated in researcher-participant reciprocal relationships which, as Kim $(2015,24)$ argues, "enables and inhibits particular kinds of insight". At all times, during the research process, I was conscious of how aspects of my social and ethno-racial identifications could potentially affect the different ways in which my participants responded to me in both group discussions, interviews and even in informal conversations. Similarly, how my identity could inform the analytical lens through which I interpreted data. My positionality and socialisation as a twenty-something-year-old, seemingly middle-class, male academic of Yoruba $^{3}$-Nigerian heritage, significantly shaped and informed how I accessed and encountered the field.

On the one hand, there were several notable benefits from occupying an 'insider position', as a Nigerian. In the main, my participants perceived me as, what is best described, in the following oxymoronic designation: an 'unrecognisable friend' or perhaps a 'familiar stranger'. This was realised in participants' behaviours towards, and cultural references of endearment for me. While there were some participants that were already known to me, for those that were not, they seemed to welcome me with open arms, and without hesitation or suspicion. Some would often describe me as, 'Orẹ ọkunrin' which is Nigerian-Yoruba masculine term, for 'my friend', or 'arakunrin lati iya miiran' meaning 'brother from another mother'. While others, used the expressions 'fam' and 'bredrin' which are Afro-Caribbean influenced, urbanised London colloquialisms, for 'family' and 'brother' respectively. Suffice to say, accessing, establishing positive initial impressions and forging a rapport with members of Nigerian communities, was relatively quick, straightforward and required no real 'grafting'. These relationships were forged by and implicated within (seemingly) shared posistionalities, 
which afforded opportunities to talk with diaspora participants unrestrictedly. So too, I had some insider knowledge and appreciation for different Nigerian practices, behaviours, and the complex subtleties of the 'how's' and 'whys' behind certain things said in interviews and group discussions.

However, being Nigerian was not a sufficient eligibility criterion for which one received full membership, it only afforded partial and provisional 'insider moments' (Kim 2015) with the studied population. There were other contextual considerations that differentiated and, at times, alienated me, from my participants and the other Nigerians that I encountered in the field. This included my age, accent and perceived social class/economic status. However, despite these 'alienating' experiences, which were few and far between relative to the more positive engagements, overall, I feel my insider posistionalities contributed to the strength and legitimacy of the empirical material. Moreover, it encouraged participants to feel comfortable to express their subjectivities in relation to humanitarian representations.

Participants were accessed in two ways. Most were assembled through a personal and social network of friends, colleagues/ex-colleagues and acquaintances. The idea was that one person would be the primary point of contact, who would either recommend and/or refer potential diaspora who they thought might be interested in the research. Or arrange a meeting with their own personal network, and further contacts would be secured thereafter through snowball sampling (Denscombe 2010). As such, personal relationships were a "primary vehicle for eliciting findings and insights" (Amit 2000, 2). In other instances, participants were accessed via gatekeepers in their places of worship and commune. Regardless of how they were recruited, all diaspora chosen to participate in the research met the criteria of focus group segmentation.

Focus group interviews were convened in locations suggested by diaspora themselves, primarily prearranged study rooms in local libraries, but also settings that they would normally socialise, such as community centres. Other locations included participants' homes and, on two occasions a rent-to-use conference room in a serviced office building. Each focus group interview involved the presentation of eight individual photos taken from humanitarian advertisements of popular British NGOs. The sampling of these visual representations was more random than purposeful, as it included publicly available images showing different themes of humanitarian issues including portrayals of poverty, human suffering and environmental crises in Africa, which were considered representative of those used by NGOs in their fund-and-awareness-raising campaigns.

Participants were encouraged to openly critique and talk about the images and, were asked a series of questions exploring, for example, their thoughts about the kind of messages they felt they communicated about Africa. This allowed the probing of broader conversations, providing interesting information about how they construe the importance of their identities when engaging with these images.

Ethical approval was sought, and all diaspora were given information about the research before considering participation. Anonymity was assured - pseudonyms are used here. The qualitative data was analysed using a thematic analysis (see Hycner 1983) looking for categories, themes and patterns relating to the broader research, this article reports on one main theme specifically. This is: 'Diaspora Resentment of, and Ethno-Racialised Identification with, Humanitarian Representations' 
This article also applies Bhabha's (1994) postcolonial 'Hybridity' concept as its theoretical framing, which suggests that diaspora identities are multiple, contradictory and iterative forms of self-identification that are constantly being defined and redefined through processes of transformation and difference in their environment. Hybridity as a theoretical concept for analysis is useful for this article. Not least as it affords space and opportunity to unearth how identity for African diaspora communities is contextual, dynamic, positional and constructive in relation to humanitarian representations in their environment, in both interesting and revelatory ways.

The following section presents the research's findings.

\section{Diaspora Resentment of, and Ethno-Racialised Identification with, Humanitarian Representations.}

Several diaspora discussants mentioned how their "race" ${ }^{1}$ and/or their ethnic ${ }^{2}$ identities as 'Black', 'African', 'Nigerian' or all three, significantly shaped how they construed and engaged with visual representations of humanitarianism. This was understood in two interrelated ways. First, in their resentment and indignation of, humanitarian representations of Africa (and communities therein) which they viewed as seemingly racist (and racialised), stereotypical and oversimplified. Second, the extent to which this engendered negative/positive associations and identifications - or lack thereof - with their continent and specific country of origin.

As a brief intermission; before unpacking the empirical material, it is important to first substantiate the appropriateness of the term 'ethnoracial' indeed 'ethnoracialised identification', for Nigerian diaspora communities. Moreover, its theoretical significance for the analysis that ensues. While Nigerians are not some vast undifferentiated horde of people inculcated in an unvaried sense of 'We', devoid of idiosyncratic elements. Diaspora populations of Nigerian heritage - in Britain - nonetheless often define themselves by and simultaneously reconcile their specific diasporic Nigerian ethnicities, alongside their racialised identifications as 'Black'. Whereby, they conceive their ethnicities as not only interconnected with their self-definitions as Black but also, as an additional nuanced complexity and/or alternative interpretation, about what it means to 'be', 'thought of' and assert oneself 'as' Black, along the lines of their cultural, historical and religious heritage(s), as well as, social class.

Indeed, in his examination of the multisided identities of second-generation Nigerian identities in Britain, Imoagene (2017) observed that rather than defining themselves as just British alone, Nigerians construe alternative iterations of black identification that differs radically from Black British Caribbean ideas of 'black'. Whereby, they balance their diasporic Nigerian ethnicity, alongside a pan-African identity, identification with fellow immigrants and their racial status. As such, as Imoagene contends and as the analysis will reveal, so much about understanding Nigerian identities in the context of 'ethnoracial' is to understand how (their) race, ethnicity, class and national context shape and inform their sense of self.

\footnotetext{
${ }^{1}$ Here, 'race' is a socially-constructed descriptor of skin colour.

2 The terms 'ethnic' and 'ethnicity' are used to refer to common identity-based cultural considerations of people in (and part of) a given geographic region, including ancestry, heritage, language, and regional customs.
} 
During group interviews, discussions about and problematisations of 'race' and racial identification, as it related to humanitarian representations were common. When these two subjects were raised, not only were they deliberated thoroughly with almost-free-verse conversational narratives, that were distinctly anecdotal, confessional, and biographical criticisms. This was when participants were also their most vocal, impassioned and allowed themselves a more censorious disposition against these images. Beyond their general 'prima facie' interpretations of these representations; the point at which diaspora conversations included their own explanations, assessments and scrutinies of race, identity (and their intersection), is where such NGO renderings of 'Africa(ns)' were interpreted as a personal, if not, a conspiratorial affront. As such, issues of race and identity -as contextualised in and through representations -necessarily spoke about a diaspora 'Self-hood', that is, a seemingly recognisable 'Self' of the individual (and supposed 'collective') diaspora, that is intimatelytied to and, constituted within visual representations of humanitarianism.

From one description to another, participants revealed how they found it difficult, and/or frustrating, indeed problematic, to engage with representations that portray "people like me" living in impoverished environments and conditions and which, trivialise Black African identities. This is exemplified in a statement by 25 -year-old Segun, who stressed:

"We [diaspora] brown skinned folk identify ourselves, albeit a grossly misshaped version of who we think ourselves to be [in humanitarian representations]. We know what they are saying about Blacks, about Africans, that we are nothing more than beggars, that we are the lowest of all the low and that's racist, without a doubt it is. It's hard to digest all these charity pictures because how do you reconcile with them when we are the very people they are racially caricaturing?"

(Male)

While another divulged:

"I find myself feeling insulted by the way in which charities caricature our homeland and fellow Africans with such buffoonery, there's some element of racism. British Africans like myself, see and critique these images from a Black African or ethnic minority perspective. I think we try to spot ways in which we feel like we are being degraded somehow through the lens of someone who actually identifies visually or culturally with Africa and African communities"

(Male, 24) 
Similarly, Judith explained:

"The elephant in the room is the role that Blackness plays in the representations of Africa and African communities. I'm of the position that images for fundraising campaigns are figurative statements about Blackness, they are political statements with negative connotations that are attached to them about being Black, knowing Blackness, conceptualising the idea of Blackness as a hue of moral and cultural difference, a hue that denotes abnormality. When this mixes with ideas of Africa and being African it chucks more fuel on the flame. We're seen as "not up there yet" and this angers me as a Black person, an African, [because] I'm involuntarily committed to the bottom of the totem pole even if it's just in my mind"

(Female, 25)

Taking such quotations in consideration, many diaspora participants have what might be best described as a specific Black 'ethonracial meaning-making' whereby they - that is, these communities - apply (self)referential interpretation positions in their analyses and consumption of NGO-produced humanitarian representations. Within this framing, their identities are foregrounded and salient as they comprehend Africa, Nigeria and communities therein, via images, especially when they portray a recognisable 'Self' construed and contorted in racially problematic and offensive ways. As such, African representation by NGOs in their campaign communications, not only affects how 'We' (the 'general public') view and imagine them, but also how 'They' -that is, Nigerian communities, interpret and visualise themselves.

These exemplar statements substantiate this, in that they necessarily foreground several important issues, hitherto undocumented within development literature, not least that, there is a certain kind of racialising of Black African identities within (and by) humanitarian representations, that is felt, and which operates for diaspora, as its most severe, onerous and problematic at the psycho-social level. Furthermore, Judith's comments demonstrate that, beyond their denotative or literal showing, visual representations of humanitarianism are much more than 'plain likeness' - seemingly innocent and unbiased. They are endowed with a constellation of meaning, of metaphorical signification, which constitute and allude to diaspora identities -their 'Black-Africanness' -as unequivocally different, indeed the pathologised 'Other'. Even if, as Judith contemplates, "it's just in my mind".

This is also observed in comments given by 42-year-old Stephanie, who shared:

"Having a Black African identity in many ways has prevented me from wanting to actively engage with images of this nature, because I'd be forced to see myself in these people and their situations. I didn't want and still don't want to see myself as them, as coming from a place that has historically birthed poverty, birthed desperation, it's like suffering has fertilised African soil and because I'm from this soil, of its people, it makes it difficult being a Black African person in the UK seeing these types of images, because many non-Blacks, ignorant white people especially, might think of you in these ways"

(Female) 
Much like Judith, Stephanie's candid and somewhat confessionary statement is revelatory, as it illuminates the fraught and problematic relationship(s) that individuals from Nigerian diaspora communities have with humanitarian representations that communicate, largely sensationalised, visual discourses and attendant messages about places and people that they identify with on account of their race, ethnicity and/or culture. The impact of which, this article will now discuss. When focus group discussants talked about these race and identity-related issues, it became apparent that their simultaneous identification with and, expressed resentment of, visual representations of humanitarianism, expressed itself in and through specific behaviours or 'diaspora idiosyncrasies'. Behaviours which are interpreted and contextualised as types of diaspora dis/association with and from their continent and country of origin (i.e. Africa and Nigeria), by adopting new, alternative and preferred identities or personae. As one discussant Francesca, plainly said:

"We deal with a psychological separation, an ingrained psychological idea of being different and this works as a self-fulfilling prophecy for some of us because we begin to resent, loath and even detach ourselves from everything and anything African. Why do you think some Africans prefer to say they are from the Caribbean? It's a form of self-hate, they don't want to be associated with images, ideas and perceptions of something so...how do I say... benighted, if that's the right word? Yes, benighted because who wants that?"

(Female, 26)

As advised by this commentator and others, the adoption of newly-acquired Caribbean identities was surprisingly an old, yet common and even, encouraged practice among UK-based African diaspora (including Nigerian communities). Several revealed how their friends, family members and they themselves, had at one point in their lives procured these alternative proclamations of 'Self'. One such example, is 32-year-old, Secondary School teacher Lola, who revealed within her group discussion how African representation by NGOs, news reportage and in popular media, profoundly affected her self-perception and levels of confidence in positively identifying with her Nigerian heritage. To such extent, that she begrudgingly identifies as Caribbean within the workplace - a reinvention of her 'Diaspora Self' that has its beginnings in her formative years at school, renegotiating the seeminglyimpenetrable terrain of adolescence:

"I mean it wasn't cool to be African at school, oh no no, ... it was even better to be gay at times [laughter] but not African! God forbid you be African. Being African meant you were dumb, lived in Jungles with animals, grunted like apes when talking and didn't care for hygiene, and what young girl wanted to be the smelly African? Not me.I got into the habit of saying I was from the Caribbean - St. Lucia or Jamaica. As far as my colleagues know that's where I originate from, it just helps to silence any potentially hurtful comments or assumptions, you know"

(Female) 
While 19-year-old Ezikiel, confessed:

"I downplay my African side. I don't willingly say where I'm from, but if people ask I just pick any Caribbean place on the top of my head at the time, Jamaica is a go-to, I'm always switching between one island or the next [laughter]... [because] the Caribbean is shown as a golden paradise, with steel bands, carnivals and cocktails not like Africa"

(Male)

Equally, Simon advised:

"There's an element of cool and flare attached to the Caribbean that Africa doesn't have, with its reggae and white sand. I think that's what attracted me to wanting to be from there, who wouldn't want "cool" attached to them?"

(Male, 27)

Caribbean identities as the default and/or preference for Nigerian participants, is due to the Caribbean's comparatively positive, almost romanticised and brochure-esque visualisation in Western-European imagination. A part of the world, which is often assumed as and, constructed in tourism marketing representation (as opposed to humanitarian aid and International Development representation) for its ebullient and celebratory culture of musicality, and rhythmic underbelly; a supposed natural hedonism for Western-situated tourists who want to indulge in its seemingly laissez-faire 'live and let live' sentiment (Smith et al., 2008). Furthermore, the Caribbean (at least some parts of it) is one of only few places within which Black majority populations are not 'always-already' subsumed in mediated representations of poverty and humanitarianism, as Africa is (Sheller, 2003; Smith et al., 2008). An observation shared, sarcastically, by this participant in her rhetorical statement:

"I mean have you ever seen a trip to Nigeria being offered as a prize on any game show? Maybe for an April fools special [laughter]"

(Female, 22)

This research observed that participant's identities are not always consciously-formed, distinct and 'certain'. Instead, they are often constituted in diaspora social consciousness as they confront the many different challenges that complicate their social and cultural mobility. This is best understood within the framing of 'everyday racism' and racial microaggression. That is, as advised by Shizha and Abdi (2014), the verbal, behavioural and/or environmental degradation that racial minority groups experience at school, the workplace and other public settings. Some participants, for example, disclosed how they 'down-play(ed)' their African/Nigerianness, and/or 'take up' Caribbean identities, in direct response to broader, negative media narratives about African and/or Nigerian communities as unproductive and fraudulent illegal migrants. 
"They [media] think Africans are all scroungers, migrants living off benefits...having countless children to exploit the NHS, that's what we get told we are, I'm not those things, none of them, I work for all that I have. I would rather be who I am, authentically, but it's easier not to"

(Female, 26)

"My white workmates use to joke that I was a Nigerian '419' scammer ... or from some sort of rough council estate, ...it was far from funny ....can you see why I don't really admit I'm from there [Nigeria]? Yes, it's embarrassing that I deny it and my parents will not be happy but there's no choice really, well there's a choice but ...yeah I don't know."

(Male, 19)

These quotations demonstrate how visual representations of humanitarianism are implicated in a much broader and complex circumlocutory system of mediated representation 'out there' about Black African identities that permeate the consciousness of diaspora populations. They are constituted in diaspora identity configurations, their comportment and degree of conviviality with and feelings of acceptance from their immediate and wider, largely white environments. This desire for equality with, and approval of, their non-African, mostly white peers, is a preoccupation shared by Nigerian participants as they manoeuvre through society assuming 'down-played' and, or preferential identities.

Listening to diaspora discussions, and taking the aforecited comments into consideration, there is a real sense of internal, psychological conflict observed among participants - a kind of diaspora identity crisis, whereby some may be experiencing and subconsciously projecting a 'Colonial Mentality'. That is, an internalised ethno-racial inferiority complex informed by diaspora histories of colonial oppressions which have afforded primacy to and, foisted ideas and ideals of white-European superiority (Okpewho, Davies, and Mazrui 2001). This has produced an anxiety-ridden diaspora, wrestling with their sense of double-consciousness i.e., their crisis of identity, autonomy and dignity (self-esteem, selfrespect, self-confidence) (Mahmod 2016). Such diaspora are necessarily lodged between their quest for white validation and their attempt at reconciling this with their internalised associations of Black/African-ness, with inferiority (Okpewho and Nzegwu 2009). These complex anxieties, amplified by media and humanitarian representations, partly inspire this forgery of new, preferential and ambivalent diaspora identities. Identity formations which on the surface appear as an escapism but nonetheless, are constraining for Nigerians. This fraught mentality is corroborated in the following discourses: 
54-year-old Immanuel who explained that:

"It's a shame as old as I am at the age of 54 you'd thought I would have reconciled with who I am and where I'm from, but It's tough...I mean you don't want white people to see you like that, you've just got to fit in somehow, someway, whether that's lying about where you're from or who you are or ...I don't know... stressing the English part of you more."

(Male)

Similarly, this participant divulged:

“As bad as it sounds it's quite freeing acting less African but it's also psychologically draining, switching from one mask or hat to the other. On one hand, you want to show your honest self and be who you are but on the other, it's not that straightforward because of people's perceptions of us. You kinda have to straddle a fine line of how you want to show yourself to white people. I'm an imposter really."

(Female, 22)

Other Nigerians interviewed managed their paradoxical relationship(s) with humanitarian representations by taking-up what can be described as inflated self-identifications, whereby they acquired rather theatrical, contrived and parodied articulations of the 'Self' which were necessarily informed by what I understood as a 'sentimental Afro-racial chauvinism'. By this I mean, they channelled their identification with and indignation of humanitarian representations, by adopting 'Afro-centric', 'unapologetically Black' and/or 'fiercely Nigerian' identities. These ethno-racial formations allow them to have protection over, demonstrate solidarity with and yet, somehow express some form of vicarious nostalgia for and pride in, Africa(ns). Contrasting the 'Caribbean adopting' diaspora, who self-admittedly, are distancing or disassociating themselves from their continent and/or country of origin, the identities of these individuals, are instead, self-celebratory and affirming. As such, their identities are repositories through which to intimately recalibrate themselves with Nigeria and Africa, even if only imagined, metaphorical or forged by some sort of pseudo romanticism of 'the homeland' or a 'collective struggle'.

29-year-old Nigel for example, passionately professed:

"I'm Nigerian and fiercely so, nothing can dim my light, not these images, charities or whatever. Gone are the days when Africans rejoiced in who they were and not let things like pictures derail their pride. I think knowing who I am and what I stand for as an

(Male)

African is greater than any damage these pictures can do to us"

While this participant opined:

"I won't stand for this portrayal of Africa or Black people, I'm like Teflon [laughter] a tough resistant Nigerian, a proud Yoruba, that can and will withstand such representations of my home, the birthplace of many of our parents if not, grandparents and those before them. If we, Black Africans are not for our own cultural homes then 
who is? It can only be us, right? It's in our veins, our ancestral DNA and therefore, I firmly believe it's our individual and collective responsibility to wear a shield of African pride, of self-love and to be loud and confident in doing so"

(Jeffery, 24)

Equally, Quentin commented:

"Why should anyone shy away from being Nigerian? I'm am immensely proud of my heritage and I'll be foolish to hide it away and apologise for that. I'm unapologetically Black, unashamedly African and that's that. If anything, all these pictures do is make my feelings stronger, make my pride firmer"

(Male, 29)

What distinguished these specific diaspora members from their 'Caribbean-adopting', 'Africa-renouncing' counterparts, was not necessarily how they identified nor their evangelism for pan-diaspora solidarity. Rather, they were predominantly university-level educated, middle-class (and aspirant), twenty-and-thirty-something-year-old, male millennials - a consortium of Nigerian diaspora intelligentsia, with a kind of retrospective meditation on, and prophetic imagining for Africa. Despite never visiting their continent/country of heritage, their ethno-racial formations are nonetheless understood as their own artillery, a form of symbolic insurgence against, resistance to and, liberation from the concretised reification of Africa's negative portrayal by NGOs and popular contemporary media within which it is sustained and implicated.

Interestingly, too, it appeared that for these Nigerians, any positive identification with Nigeria/Africa conferred and/or legitimised their membership and exclusivity with an established (and emergent) Black racialised intellectual minority elite class, signified by inter/nationally revered Nigerian/African intellectuals and artists such as, Chimamanda Adichie and Yinka Shonibare. For them, acquiring ambassadorial African identities reflected a certain self-fashioning prestige, seemingly possessed and demonstrated by highly-educated middle-and-upper-class communities of African heritage, who they assume have (and advocate for) an intuitively profound Black racial consciousness.

Whether assuming an 'ambassadorial' or anti-Black African position, I understood these subjectivities as a strategy against the racialised subordinate position that some contemporary Nigerians find themselves in the UK. That is, as assumed constituents of the less-privileged Black proletariat (despite their high educational aspirations and attainment level), reinforced by humanitarian representations and other problematic media reportage and stereotypes of Nigerians and Africa(ns) generally. As such, these contemporary ethno-racial formations are summoned and utilised to either affirm/maintain their always-already selfperceived middle-class identity status (as is the case for several Africa(n)-identifying diaspora). Or if not, used to seemingly 'fast track' or confer one's own eligibility to this desired (and seemingly preferred) social class stratification. In this sense, these identities could also be interpreted as a vehicle through which some diaspora attempt to reify, preserve and/or access their perceived/desired social class by consolidating disparities between how they view themselves set against how they are perceived and received by the world (Adjepong 2018). 
However, it is important to reiterate here that this class-based subject-making is also fundamentally about Nigerian's distancing themselves from humanitarian representations of the Black African poor (and attendant connotations) which is necessarily implicated within (and regurgitate) the white supremacist ideology of 'dividing and conquering the Black Other'. That is, Nigerian's desire for and repositioning to new and preferred social stratification -as an attempt to demarcate themselves from imageries of Black African privation -is based on "Whiteness". Whereby, through the process of negotiating these alternative identities, Nigerians' acquire a new criterion of whiteness ideology upon/through which they measure themselves against the racialised Black African poor 'Other'. In this sense, - as is the function and materialisms of white supremacism - Nigerian identity formations reproduce inverse relationships with the Black African poor where the latter is assumed fundamentally different and as being everything that the Nigerian diaspora 'is not' but 'should' and 'ought to be' (Pierre 2004).

Not only does this play into, and ventriloquise hegemonic particularities of whiteness, by appropriating its "them/us" binary oppositions used to sift, sort and organise the non-white, Black 'Other' into seemingly normative hierarchically racialised distinctions. It also, fuels new forms and discourses of anti-Black racialised separatism, fragmentation and hierarchies among Nigerians themselves. That is, an inter-and-intra-diaspora-continental Nigerian division, materialised through (perceptions of) class status but necessarily constituted in and historicised by white supremist discourse. This further subjugates and marginalises those Nigerians and 'the Black African poor' at the bottom, as they are viewed and assumed as inferior, inherently 'different' and as lacking the 'appropriate' eligibility criteria to access higher class stratifications (Adjepong 2018).

When contextualised within Bhabha's Hybridity theorisation, we understand that Nigerian identity (re)configurations are necessarily implicated in, and constitutive representations of humanitarianism. Beyond their materiality, these iconographies of humanitarianism in (and of) Africa provide the discursive space and resource from which Nigerian's (re)claim new forms and axes of self-representation, visibility and voice, to affront and contest the locus of whiteness and its meaning-making imbued within NGO communications which often negatively portray their continent and/or country of heritage in ways that are racially problematic.

Not only does this suggest a certain performativity, dynamism, multidimensionality and transformational potential of diaspora identities, in relation to humanitarian representations but also, that the appropriation of these newly-purchased, alternative and preferential identifications are fundamentally performances of a 'postcolonial Selfhood'- that is, they are material and figurative forms of diaspora agency. Whereby, diaspora communities become their own 'walking and talking' PR machine, exercising autonomy and (self)determination in how they are viewed and received by immediate and wider publics, with meticulous and determined precision. As such, these artisanal identities are strategically summoned and utilised to reconcile perceived incompatibilities and the cognitive dissonance, between how they want to be 'seen', versus how they are mediated in NGO representational forms. For Nigerians, this acts as a psychosocial cushioning and is a contingency against the brunt of problematic and harmful representations in their everyday lives. In this sense, they exert some level of authorship, manoeuvre and flexibility over their self-iterations and subjectivism in the public sphere; a privilege for which they would otherwise be ineligible for in humanitarian 
representations which seem to offer fixity, a degree of aesthetic certainty, in how Africa(ns) 'ought' to be seen and (is historically) known by Western-situated publics.

This is further substantiated by 32-year-old Merideth who mentioned:

"Being anything but African means I determine the terms of who I am and how others might see me. I can make sure I'm seen more favourably"

(Female)

Equally, this group discussant explained:

“They haven't just been images but [they] have told a story about my identity and my place of birth, on my behalf, without permission, a story that many white people, nonBlacks have interpreted as gospel, these images have influenced with some great force how I decide to show myself to other people. I'm in the driver's seat now"

(Male, 54)

While there are (some real and perceived) affordances of these negotiated positionalities in terms of Nigerians' exercising some degree of self-determination and choice over how they are seen and received in their micro-environments. It would be incredibly remiss of me to discount (and not problematise) the institutional limitations of these diaspora identities, and their assumed levels of agency, freedom and 'transformative potential'. Especially given the structural-historical realities of whiteness within which the identities of marginalised Black racialised communities are necessarily situated and subject(ed) to. As such, while the postcolonial conception of hybridity, fluidity and flux, are confrontations against essentialised attempts at normalising monolithic and 'authentic' forms of racialised identity (Bhabha, 2013). It is impetuous to suggest the diminution in the ideological and material supremacism of whiteness; whereby Nigerians' self-representations are somehow conflated with parity.

Within this frame, Nigerian's own subject-making isn't constituted within some boundary-less discretionary choice that is independent of whiteness but rather, fixed within the ineluctable limitations of two main definitional possibilities -self-defining as either African or Caribbean. As such, these 'choices' (or lack thereof) are always-already preassigned by white supremacism and its racialising of the Black 'Other'. Nigerians' Blackness therefore provides as structural narrative that limits their assumed sovereignty of choice and plasticity in selfrepresentation given their inaccessibility of non-Black identities (Pierre 2004)

Regardless of whether diaspora participants perform identities that associate or dissociate from their continent and communities of heritage; their (brown) skin colour and ethno-racial identities as Black, Nigerian and/or African, is significantly implicated in their consumption and analysis of visual representations of humanitarianism and their perspicuity of their impact in relation to how they construct perceptions of who they are - yet still, who (or what) they aspire to be or 'claim'. This is particularly apparent in the different ways that 
diaspora establish levels of identification with similarly-looking, and seemingly recognisable 'others' within images and how this is constituted in their everyday lived-realities and selfconcepts. As evidenced here:

"I see myself in the context of these images, they are talking about me, us, aren't they? My existence, my presentation, the histories of Black Africans, you can't de-link that or yourself from these types of charity images, can you?"

(Bethany, 48)

"I see these Black-skinned faces and bodies and I unavoidably see myself. I see no difference but circumstance. I step into their shoes in a way, and I feel the same weight of judgement, scrutiny and perceptions placed on them on my own shoulders. I feel it on a visceral level. It's a self-fulfilling prophecy about African's ... about Nigerian's that I want to avoid"

(Abigal, 24)

While these commentaries provide interesting and critical understandings of the influence that humanitarian representation has on identity for Nigerians; it is important to note that this evidence does not claim some sort of unidirectional causal relationship between these representations and Nigerian subject-making, that is seemingly self-evident, deterministic and an authoritative truth. Such conclusions are problematic as they determine law-like regularities among Nigerians but also, they underemphasise the capacity and agency of Nigerians as active appropriators and (re)negotiators of meaning who are intellectually engaged in, reconcile with and even resist their environments. Rather, the evidence empathises the significance of representations for Nigerian identity configurations.

\section{Conclusion}

This article makes important and unique contributions to mainstream and critical scholarship in the interconnected fields of African diaspora identification and humanitarian/NGO representations. Specifically, it adds new knowledge to the existing examinations of identities for first-and-second-generation Nigerian communities living in the UK. While current studies have examined the varied roles that humanitarian representations play in how (and the extent to which) largely white Western-situated people understand and engage with distant 'Others'. Little attention has been paid specifically to the black marginalised experiences and perspicuity of Nigerian diaspora communities who locate their ethno-racial heritages in places and among the communities that are portrayed in these representations.

Appropriately, it has revealed an interconnectedness between depictions of African privation in humanitarian representations and Nigerian identity-formation. Whereby, Nigerian subject-making is necessarily implicated in, constituted through and even against, these forms of visual mediated communication. This is most pronounced in the paradoxical relationships that Nigerians have with humanitarian representations - which is primarily defined by their simultaneous resentment for and identification with these images, as they respond to the seemingly unavoidable difference through similarity that they produce. These oxymoronic, "harmoniously-conflicting" relationships are managed by Nigerians adopting and 
(re)appropriating new, alternative and preferential racialised identities or 'personae' such as the 'taking up' of Afro-Caribbean identities that 'downplay' their Nigerian and/or Africanness. With others, acquiring 'ambassadorial' and self-celebratory identities as "unapologetically Black" or "fiercely Nigerian" that uplift their ethno-racial subjectivities.

These newly-formed Nigerian self-iterations are strategically mobilised in their attempt to make 'meaning' legible in the semiosis of racially stereotyped and problematic portrayals of Africa(ns) - that are mediated by the supremacism of whiteness. So too, to mitigate preoccupations about their cultural (un)palatability to society's white hegemony. These identities are also class-based; adopted to access and mimic the social optics and comportment of middle-class statuses, while attempting to disassociate themselves from imageries of 'the Black African poor'. Not only does this ventriloquise whiteness ideologies, by appropriating its "them/us" binary oppositions used to systematise the non-white, Black 'Other' into seemingly normative hierarchically-racialised distinctions. It also fuels anti-Black racialised sentiments and hierarchical divisions among Nigerians that are undergirded by whiteness.

Similarly, while findings support Bhabha's theorisations of diaspora identities as fluid, open to negotiation and creativity, where new opportunities of identification emerge. They complicate current debates by demonstrating that diaspora subjectivities, are just as open to being essentialised. Whereby, Nigerian subject-making is not independent of, but rather implicated in (and historicised by) whiteness, which always-already predetermines the options for Black racialised identities - African or Caribbean. Nigerian's Blackness therefore provides as structural narrative that limits their assumed 'choice' and 'freedom' in self-definition given their impenetrability of non-Black identities.

Moreover, by examining Nigerians as an audience type, questions and problematises how we currently comprehend and theorise the nature and composition of British audiences of humanitarian representations, as seemingly straight-forward and obvious. It does this specifically by encouraging an epistemological and attitudinal shift in how we conceive nonwhite, Black racialised Nigerian communities, as somehow invisible and/or undifferentiated from seemingly all-white audiences. As such, it necessarily resists the homogenising pressures of treating audiences (and their subjectivities) as a horde of collectivities devoid of individual articulation of unique intent and which Nigerians coalesce.

\footnotetext{
${ }^{1}$ Here, 'whiteness' is the omnipresent, invisible and unmarked standard with which non-white "others" are judged and declared to deviate. It is a relational category that is parasitic on 'Blackness' (Willoughby-Herard 2016).

${ }^{2}$ Here the term 'ethnoracial' is not just a portmanteau of 'ethnicity' and 'race' but also refers to how Nigerian's
ethnic and racial identification are mutually-inclusive.

${ }^{3}$ A Nigerian ethnolinguistic community.
} 


\section{References}

Ademolu. E, and S. Warrington. 2019. "Who Gets to Talk About NGO Images of Global Poverty?" Photography and Culture, DOI: 10.1080/17514517.2019.1637184

Adjepong. A. 2018. "Afropolitan projects: African immigrant identities and solidarities in the United States". Ethnic and Racial Studies, 41(2), 248-266.

Agarwal. R., and Andrew W. H. 2002. "Are International Remittances Altruism or Insurance? Evidence from Guyana Using Multiple-Migrant Households". World Development 30(11): 2033-2044.

Alakija, B.O. 2016. "Mediating Home in Diaspora: Identity Construction of First-and-Second Generation Nigerian Immigrants in Peckham, London.” PhD diss., University of Leicester.

Bhabha, K. H. 2013. “Culture's In- Between”. In Questions of Cultural Identity, edited by Hall, S. and Du Gay, 53-60. London: Sage.

Chouliaraki, L. 2006. The spectatorship of suffering. London: SAGE Publications.

Darnton, A. and Kirk, M. 2011. Finding Frames: New ways to engage the UK public in global poverty. London: DFID.

Denscombe, M. 2010. The Good Research Guide: For Small-Scale Social Research Projects: For Small-Scale Social Research Projects. Maidenhead, England: Open University Press.

DFID. 2000. Viewing the World. London, DFID.

Dogra, N. 2012. Representations of Global Poverty. London: I.B. Tauris.

Gilbert, N. 2008. Researching Social Life. London: Sage.

Hall, S. [1973], 1980. "Encoding/Decoding”. In Culture, Media, Language: Working papers in cultural studies, edited by Hall, S, 129-138. London: Hutchinson.

Hyncer, R. 1985. "Some Guidelines For the Phenomenological Analysis of Interview Data." Human Studies 8: 279-303.

Kennedy, D. 2009. "Selling the Distant Other: Humanitarianism and Imagery - Ethical Dilemmas of Humanitarian Action.” Journal of Humanitarian Assistance, 28 1-25.

Kim, H. 2015. Making Diaspora in a Global City: South Asian Youth Cultures in London. Abingdon: Routledge.

Moeller, K. 2018. The Gender Effect: Capitalism, Feminism, and the Corporate Politics of Development. Oakland, California: University of California Press.

Okpewho, I., Davies, C. and Mazrui, A. A. 2001. The African Diaspora: African Origins and New World Identities. Bloomington, USA: Indiana University Press. 
Okpewho, I. and Nzegwu, N. 2009. The New African Diaspora. Bloomington, USA: Indiana University Press.

Onoso, I. 2017. Beyond Expectations: Second-generation Nigerians in the United States and Britain. USA: University of California Press.

Pierre, J. 2004. "Black Immigrants in the United States and the "Cultural Narratives" of Ethnicity. Identities", identities, 11(2):141-170.

Sheller, M. 2003. Consuming the Caribbean: From Arawaks to Zombie. London: Routledge.

Shiza, E. and Abdi A. A. 2014. Indigenous discourses on knowledge and development in Africa. New York: Routledge.

Silverstone, R. 2007. Media and morality: On the rise of the mediapolis. London: Polity.

Smith, D., Puig, R. and Santiago, I. 2008. Caribbean Without Borders: Literature, Language and Culture. Newcastle upon Tyne: Cambridge Scholars Publishing.

van der Gaag, N and Nash, C. 1987. Images of Africa: The UK Report, London: Mimeo.

VSO. 2001. The Live Aid Legacy: The Developing World Through British Eyes -A Research Report, London: VSO.

Willoughby-Herard, T. 2015. Waste of a White Skin: The Carnegie Corporation and the Racial Logic of white vulnerability. Oakland, California: University of California Press. 